\title{
The First Catholic Bible in Chinese: Gabriele Allegra and His Translation
}

Abstract: Christian missionaries play an important role in the history of the relationship between China and Europe. Their presence in China has been widely explored, but little attention has been paid to the role played by the Bible in their preaching.

From $13^{\text {th }}$ to $19^{\text {th }}$ century, although they did not translate the Bible, Catholic missionaries preached the Gospel orally or with catechisms. On the other hand, the Protestant missionaries had published many version of the Chinese Bible throughout the $19^{\text {th }}$ century.

It was only in the $20^{\text {th }}$ century that the Franciscan friar Gabriele Allegra decided to go to China as a missionary to translate the Holy Scriptures into Chinese. He arrived in China in 1931 and translated from 1935 to 1961 . He also founded a biblical study centre to prepare expert scholars to collaborate in the Bible translation. Allegra and his colleagues completed the translation in 1961, and the first complete single-volume Catholic Bible in Chinese was published in 1968.

After presenting the historical background of Allegra's activity, a textual analysis of some passages of his translation will be presented, emphasizing the meanings of the Chinese words he chose to use to translate particular elements of Christian terminology. This study will verify the closeness of the work by Allegra to the original Greek text and the validity of some particular translation choices.

Abstract (Italian): Ogni fase della presenza dei missionari cristiani in Cina è stata caratterizzata da una modalità di evangelizzazione diversa, dal XIII al XX secolo. I primi missionari annunciavano i contenuti della loro dottrina oralmente, parafrasando in cinese i contenuti delle Sacre Scritture. Successivamente, alla predicazione orale fu affiancata la compilazione di testi cristiani direttamente in cinese, ma, fino al XIX secolo, non esisteva una traduzione completa della Bibbia in cinese.

I primi a occuparsi ufficialmente della questione furono i missionari protestanti. Essi arrivarono nel sud della Cina all'inizio dell'Ottocento e in meno di un secolo prepararono e pubblicarono numerose versioni parziali e integrali delle Scritture in cinese. Nel 1928 Gabriele Allegra, un giovane francescano italiano, venne a conoscenza dell'assenza di una traduzione completa della Bibbia in cinese per i cattolici e decise di dedicarsi a tale missione. Egli giunse in Cina nel 1931 e nel 1935 iniziò la sua traduzione. Per la prima volta venivano usati i testi originali per tradurre la Sacra Scrittura in cinese e il lavoro veniva basato su metodi scientifici e moderni di esegesi e traduzione. Nel 1968 fu pubblicata la prima Bibbia cattolica cinese in volume unico. Questo testo è usato ancora oggi nel mondo cattolico cinese e, per questo motivo, risulta essere un testo interessante da analizzare. 
Dopo aver brevemente presentato la situazione storica in cui contestualizzare la versione in esame, saranno percorse brevemente la vita e l'attività di traduzione di Allegra. Saranno poi esposte le caratteristiche della traduzione e analizzate alcune scelte specifiche riguardanti il lessico del Nuovo Testamento. Scopo dell'analisi è la verifica dell'aderenza della traduzione all'originale greco e della validità della traduzione stessa.

Keywords: Chinese Bible - translation of the Bible - Christianity in China - Franciscans in China - Chinese Christian terminology.

\section{Introduction}

In 1928 the Franciscan Friars celebrated the sixth centenary of the death of their confrere John of Montecorvino, the first bishop of China. Among the participants in the solemn assembly held at the International College of Saint Anthony in Rome, there was a also a young friar from Sicily, Gabriele Allegra. During the conference he came to know that the Catholics in China did not have a complete translation of the Bible in their language and he was very dismayed by this fact. That day he decided to become a missionary to China and to go there to translate the Holy Scriptures in Chinese. This was the starting point of his activity that will be outlined in this article.

The translation of Allegra is of great importance for the Chinese Catholics for several reasons. First, it is the first complete Catholic version in Chinese, as previously there had been only partial translations. Secondly, it is the first Chinese version made from the original Hebrew and Greek texts, as previous versions were made from Latin or English texts. Thirdly, Allegra and his team of scholars worked using scientific principles of translation and exegesis, and their activity was supported by the Pope and other representatives of the church hierarchy. This translation, published in 1968 in a one-volume version, is still used today by the Chinese Catholics, and, due to the reasons aforementioned, is worthy of analysis.

Before focusing attention on the life and work of Gabriele Allegra, the historical context in which it was situated will be presented. Afterwards some biographical information will be given and then the translation, with its history and features, will be analyzed. Finally, through textual analysis of some relevant passages and lexicon of the New Testament, it will be possible to verify the adherence of the translation to the previously set principles.

\section{Historical background}

The presence of Catholic missionaries in China dates back to the $13^{\text {th }}$ century, when the first Franciscan friars arrived at the court of the emperors 
of the Yuan dynasty. They were John of Pian del Carpine and Benedict of Poland, who arrived in Karakorum (near what is now Beijing) in 1246. The Pope had sent them to China with diplomatic roles, so they did not preach the Gospel, nor did they translated Christian texts into Chinese. In $1293^{1}$ another Franciscan arrived in China - John of Montecorvino. He was the one Allegra heard about in 1928, and, thank to his successful missionary work, he was appointed as the first bishop of China. From his letters we know that he built the first church in China, baptized several Chinese, and, at the beginning of the $14^{\text {th }}$ century, translated the Psalms and the New Testament into the Mongolic language. Unfortunately, his manuscripts have never been found.

The Franciscan missionaries in China who followed usually preached the Gospel orally and translated the stories of the Bible verbally to explain them to Chinese people. In those centuries, translating the Bible into Chinese was not a priority for the missionaries as Latin was the official language of the rites and the liturgies of the Catholic Church throughout the world. Furthermore, the Christians did not have direct contact with the Holy Scriptures; books were expensive and illiteracy was widespread, so a Chinese Bible was simply not needed. It was only in the first half of the $18^{\text {th }}$ century that some Franciscans had a correspondence ${ }^{2}$ relating to the Chinese translation of some books of both the Old and the New Testament. As for the manuscripts of John of Montecorvino, these translations have also never been found (Zetzsche 1999a, pp.25-27).

In the $16^{\text {th }}$ century the Jesuits arrived in China, receiving a warm welcome from the scholar-bureaucrats of the Ming dynasty because they presented themselves as well learned in Western literature, geography, mathematics, astronomy, and architecture. Being considered as cultural and scientific representatives, the Jesuits in China established close relationships with Chinese scholars and assigned a primary role to books in their missionary work ${ }^{3}$. They wrote and translated the most important books of the Chinese culture into European languages, as well as writing and translating many Western books into Chinese. Among these books, however, the Bible was missing. This was "a question of priorities" (Standaert 1999, p.37); the missionaries of the Society of Jesus, in their preaching, preferred to publish books that were more direct than the Bible - which would have required deep explanations. They compiled illustrated books, translated the missal and the breviary, wrote catechisms and other simple books of prayers with the aim of transmitting their doctrine to the Chinese in the easiest and most effective way. They also preached orally, telling biblical stories and explaining them to their Chinese listeners. Although they did not include literal Bible translations, all of these activities of writing and translating contributed to the gradual creation of a Chinese Christian terminology (Standaert 1999).

Among the Jesuits, only the French missionary Louis de Poirot (1735-1813), at the end of the $18^{\text {th }}$ century, undertook the translation of the Bible. Poirot 
translated the Latin Vulgate into a colloquial Chinese: the Güxīn shèngjīng (古 新聖經, “Old and New Holy Classic"). This version was over than 34 volumes and included the complete New Testament and the partial Old Testament. It took Poirot around fifty years to translate the Bible, and, for the first time, he added a short explanation of each book of the Scriptures. His work was praised, but the Sacred Congregation for the Propagation of the Faith prohibited Poirot from publishing it (Standaert 1999). This reaction of the Congregation was based on its 1655 decree prohibiting the missionaries from printing any book without its permission. This same decree prevented another French missionary from publishing his translation, as well. He was Jean Basset (16621707) of the Missions Étrangères de Paris (MEP), who, by the beginning of the $18^{\text {th }}$ century, had translated almost the entire New Testament from the Latin Vulgate into colloquial Chinese ${ }^{4}$. These two manuscripts, though not published, were both precious and useful for the following translations. In fact, the version by Poirot was later found by Allegra in the Jesuit Library of Beijing, while a transcription of the version by Basset was conserved in the British Museum and used by the first Protestant missionary in China, Robert Morrison 5 .

Robert Morrison was the first of a series of Protestant missionaries who, from the beginning of the $19^{\text {th }}$ century, arrived in China, with their most important task being that of translating the Bible in Chinese. Morrison arrived in Canton in 1807, starting straightaway his Chinese Bible translation, which was published in $1823^{6}$.

In less than a century the Protestants published many complete and partial versions of the Holy Scriptures, using literal Chinese, colloquial Chinese, and even local dialects. Every denomination used to translate its own version, but this created inconsistencies and confusion among the Chinese readers. Furthermore, the translations were often made from different English versions of the Bible, and this resulted in different Chinese versions with varying terminology. Only in 1858 was a complete translation of the Bible published - under the name of Delegates' Version (Zetzsche 1999a, pp.77-110) - as the product of the joint efforts of the delegates of different missionary stations that had decided to collaborate in translating. A similar project was undertaken at the end of the century and was completed in 1919 when the so-called Union Version (Zetzsche 1999a; 1999b) was published. This translation was the most appreciated and widely used version of the Bible in China by all of the Christian denominations.

After 1919 many other protestant translations and revisions were published. The Union Version, however, remained as a landmark in the history of Chinese Bible translation. In the first decades of the $20^{\text {th }}$ century there were also some attempts by the Catholics to officially translate some relevant passages of the Holy Scriptures in Chinese, but these were rather partial and not scientific $^{7}$. 
It was against this background that Allegra decided to translate the whole Bible in Chinese from the original texts and with a solid scientific base. Indeed, as Camps (1999, p.57) points out, "[Allegra] would have liked more scientific supervision, clearer exegetical principles, and especially knowledge of the biblical languages by the Chinese who assisted in the work of translation".

\section{Gabriele Allegra: missionary and translator}

Giovanni Stefano Allegra was born in Sicily in 1907 and at the age of 11 entered a Franciscan seminary near his hometown. In 1924 he took vows, taking the name of Gabriele Maria. Then, in 1926 Allegra moved to Rome to study theology and missiology ${ }^{8}$. It was there that he attended the abovementioned conference on John of Montecorvino, and it was on that occasion that he became acquainted with the situation of the Catholics in China. In his autobiographical memoirs ${ }^{9}$, Allegra described his reaction to what he heard as a, "burning fuse near a powder keg," and as an, "electric shock," (Oppes 2005, p.62) - a feeling so strong that he could not remain in Italy anymore, and he immediately asked for permission to leave for China. His superiors accepted his request and allowed him to begin his preparation, studying Sacred Scriptures, biblical languages and exegesis. In 1930 he was ordained as a priest, and in 1931 he received permission to go to China. Nevertheless, the mission his superiors assigned him was different from what he expected; in China he would have been the spiritual director of the Franciscans' minor seminary in Hengyang. At first he was disappointed with this role, having in his heart the dream of translating the Holy Scriptures, but he left anyway. Allegra arrived at Hengyang, in the Hunan province, in July of 1931, after about two months of sailing. When arrived in China, Allegra started to study the Chinese language and culture, read the Chinese Five Classics (Wüjing 五經) and the Four Books (Sish $\bar{u}$ 四書) and trained in translating to and from Chinese.

During his first period in China, Allegra spent time and energy in studying both Chinese language and the Holy Scriptures. His daily timetable included five hours studying Chinese language and Sinology and three hours studying the Bible, exegesis and biblical languages. He reserved the remaining hours of each day to accomplish his tasks as spiritual director, and then immersed himself in personal prayer, spiritual readings, and meditation (Oppes 2005, p.82). As reported by Camps (1999, p.61): "in his autobiography Gabriele mentions the many books he studied, and it is evident that he became a real scholar". His first activity as "a real scholar" was that of forming a specialized library for the study of the Bible: from Italy he had brought books on the Old and New Testament, dictionaries of the biblical languages, theology and exegesis books, as well as the Latin and Italian Bibles. Afterwards, he 
studied the old Protestant biblical magazines and missionary bulletins. When he learned of the translations by Basset and Poirot, he tried to get them; he asked for a copy of the Basset manuscript to be sent from London and he went to Beijing and took photos of the Poirot's version preserved in the Beitang library.

In 1935 he was able to start his translation of the Bible, beginning from the first book of the Old Testament, Genesis. He continued the translation despite the outbreak of the Second Sino-Japanese war in July of 1937, and despite the great hardships of the war. In the same years he also translated into Italian the famous poem by $\mathrm{Qu}$ Yuan (屈原), $L i$ Sāo (離騷 “Encountering sorrow"), which was published in Shanghai in 1938 (Oppes 2005, p.89; Qu Yuan 1938). Allegra eventually worked too hard in studying and translating, because in 1938 he had a neurasthenia attack and was forced to go back in Italy to be cured.

While in Italy - having recovered - he attended some courses on the Holy Scriptures at the Pontifical Biblical Institute in Rome and continued to find and buy useful books to bring to China. After spending some months in the Holy Land, he was offered a position as professor of history of religions at the Catholic University of Milan, but he refused because, "the urge to return to China and to continue his Bible project prevailed" (Camps 1999, p.61). He was then appointed as chaplain of the Italian embassy in Beijing, and was able to leave in December 1940. Unfortunately, the Second World War had broken out and it was difficult to travel abroad, so he had to reach China via Lisbon-New York. He flew - for the first time in his life - from Rome to Madrid and from Madrid to Lisbon, where he boarded a ship to New York. He then traveled to San Francisco by train, from there sailing to Kobe. In Japan he met the Jesuit Father Teilhard de Chardin, with whom he formed a close friendship (Allegra 1966). From Kobe, he boarded a ship to Shanghai and, from there he arrived in Beijing by train (April 26, 1941). When he met the Apostolic Delegate in Beijing he told him that he did have not to worry about the chaplain role, and that he had to devote all of his time to translating the Bible into Chinese (Oppes 2005, pp.97-98).

Allegra accepted this invitation and continued the translation of the Old Testament, successfully completing it by November 21, 1944. Before being able to publish it, he felt the need to create a team of scholars that could help him in reviewing the Old Testament and translating the New. To this end, he chose some European scholars skilled in biblical studies and five Chinese friars to collaborate. The Chinese members were: Solanus Li Zhixian, Bernardinus Li Yutang, Antonius Li Shiyu, Ludovicus Liu Xutang and Victor Zuo Tianzhun - all graduate friars of the Furen University in Beijing. On the $2^{\text {nd }}$ of August, 1945, having formed this team, Allegra founded the Studium Biblicum Franciscanum Sinense in Beijing. It was a research centre on the Bible with the aim of supporting the spreading of the Scriptures in China. 
The role of Allegra's collaborators was that of improving the translation, introductions and notes on the Old Testament which he had prepared. Later, they would work together on the translation and edition of the New Testament. The first official activity of the Studium was the publication of the Chinese Book of Psalms in 1946, and one year later the statutes of the institution were approved.

In 1948 the Studium had to be moved to Hong Kong, and gradually all the members moved there to continue their work of translation. Each day at the Studium was organized by a strict timetable, according to which, after one hour of debate on the translating problems, every translator had to work individually on the texts for five hours a day. That daily hour of debate, for more than twenty years, was the most helpful means to achieve uniformity of method and linguistic and interpretive coherence (Oppes 2005, pp.121123). To improve the biblical knowledge of the translators, Allegra decided to include a period of study and research in the Holy Land in their training. There they could study the original biblical texts, as well as live in and visit the places where Jesus had lived and where the Bible had been written ${ }^{10}$. The first of these research trips was from the end of 1954 until June 1955.

In 1957 the translation of the New Testament began. It was published in three volumes, the last of these being printed in 1961, completing the whole version of the Bible. Meanwhile Allegra continued to engage in other activities such as that of founding a Sociological Studium in Singapore ${ }^{11}$ or of collaborating with the Protestant groups in Hong Kong. For example, the team of the Studium, together with some representatives of the Protestant Church, organized the so-called "Biblical Exposition" of Hong Kong (April 20-22, 1965) ${ }^{12}$, following an Inter-confessional Biblical Conference (January 27-29, 1965) in which the American Bible translator - and Secretary of the American Bible Society - Eugene Nida also participated. Allegra and his collaborators also participated in some conferences of the Bible Societies, showing in this way their respect and admiration for the activities of the Protestants.

In the meantime, Allegra was content with the eleven volumes of the Chinese Bible, however he still wanted to give the Chinese people something more accessible and practical for reading and understanding the word of God. For this reason, as soon as all the volumes were edited, the team of the Studium started to review the whole translation and, in 1968, they were able to publish the one-volume Chinese Bible. As it was published and distributed on Christmas Day, it goes by the name of Betlem Bible or Christmas Bible, or even Scotus Bible (Sīgāo Shèngjīng 思高聖經) ${ }^{13}$, since the Franciscan Duns Scotus was the patron of the Studium, along with the Virgin Mary. Allegra celebrated the printing of the one-volume Bible by going to see his leper friends in Macau. During all those years, despite his scholastic activity, he had indeed never stopped being a missionary, preaching spiritual exercises in 
Europe and East Asia, writing Gospel meditations, absolving penitents, and visiting the sick, among whom the lepers were his most beloved.

To avoid the possibility of misunderstandings by the Chinese Catholics who read the new version of the Bible and to give them all the means necessary to better understand the Scriptures, Allegra and his collaborators, as the onevolume Bible was published, started to compile a Chinese Biblical Dictionary (Shèngjīng cídiăn 聖經辭典) to collect and clearly explain all the biblical terminology, proper names, place names as well as zoological and botanical names. Every member of the Studium - Allegra included - worked on many definitions for this Dictionary, which was finally published on April 15, 1975. Every explanation in the Dictionary had to be, "short, clear and concise" (Oppes 2005, p. 172). It also included some articles on other religions, biblical theology, archaeology, Bible translation, as well as chronological tables and double transliterations of the proper names: Catholic and Protestant. Some months later, Allegra was asked to write his autobiography - the main source of information today about his life and activity. In it he underlined how every purpose of the Studium had been achieved, including: the translation of the Bible, the comments and introductions, the review and the one-volume edition, the biblical dictionary, the Biblical Association and the biblical magazine ${ }^{14}$. It seemed to be a sort of "last work", as from 1969 he had been suffering of heart and respiratory diseases, and, on January 26, 1976, he died during a surgery in a Hong Kong hospital.

\section{Sigao shengjing: history and features}

As presented above, the main task of Allegra's life was that of giving a Chinese Bible to the Chinese people, and every event in his life seems to have contributed to that purpose. In this section the features of the Sigga o Shèngjīng will be presented.

Having already started the study of biblical languages and exegesis in Italy, Allegra devoted much of his time and energy in China to the study of Chinese language and culture. He soon was able to master the new language, and, four years after his arrival in China, he started his translation (April 11, 1935).

Before translating, Allegra established some guidelines that he intended to follow in order to base his version on strict scientific principles (Allegra 1953a, pp.209-216; 1965, pp.346-347). The first of these was to translate from the original text: "Hebrew, Aramaic and Greek, using for such work the most recent and the most critical editions of the Bible" (Allegra 1965a, p.346). The second principle to apply, as far as the Old Testament was concerned, was that of correcting difficult passages of the Masoretic text according to ancient Greek, Latin and Syriac versions. Furthermore, Allegra wanted that he and his collaborators also study the best modern and contemporary biblical translations 
and exegesis such as the International Biblical Commentary, the collection Etudes Bibliques, the Bonner Bible, and the Garofalo Biblia. Concerning the Chinese language, Allegra (1965a, p.347) wrote: "we proposed to keep in the Chinese language, as far as possible, the flavour of the original Semitic texts [...] As for the language into which the Bible must be translated, we chose the modern national language: kuo yu (國語)". Additionally, regarding the important issue of Christian terminology, Allegra (1965a, p.348) reported that the majority of the words chosen came from the Christian tradition dating back to $16^{\text {th }}$ and $17^{\text {th }}$ centuries, and that, "we limited our activity to sometimes correcting the ancient terms, although for certain words we had to form new ones; however, these newly-coined words are not so numerous, perhaps forty or fifty". On the very "complex and troublesome" (Allegra 1965a, p.350) aspect of Bible translation - the translation of proper names, the translators refused the idea of creating new two or three-character Chinese words and instead adopted a clear system of transliteration. To this end, two rules were established: those names most used (Jesus, Mary, Adam, Eve, etc.), already transliterated in Chinese and accepted by a long tradition, would not be changed. For the other names, Allegra and his co-workers chose a method, "based for one part on the romanization (Kuo Yin Tse Mu 國音字母) proposed by a special Commission of the Central Government in the years 1930-34, and, for another part, on the spelling of the original language: Hebrew, Greek, Aramaic, etc." (Allegra 1965a, p.350). As far as the proper botanical and zoological names were concerned, it was established that translation would be based on the most recent specialized Chinese dictionaries and scientific papers (Allegra 1953a, p.213).

Using these principles, in the years from 1935 to 1961, the whole Bible was translated and published in eleven volumes; the first eight books were of the Old Testament and the last three of the New. The first publication was that of the Psalms in 1946, followed by the volume of Wisdom (1947) and the Pentateuch (1948). In 1949 and 1950 the two volumes of the Historical Books were published, and in 1951, 1952 and 1954 the Old Testament was completed with the printing of the three volumes of the Prophetic Books. In 1957 the Studium team published the first volume of the New Testament the four Gospels, followed by the volume of the Acts of the Apostles and the Pauline Epistles in 1959, and the tome with the other epistles and the Book of Revelation in 1961. These eleven large volumes were published together with their relevant introductions, notes and commentaries, as those were the first means help Chinese Catholics better understand the Holy Scriptures before the publication of the Biblical Dictionary. In particular, regarding the commentaries, Allegra (1965a, pp.351-352) wrote:

It was also our intention, in writing the commentaries, to follow the principles laid down by Pius XII in his encyclical Divino Afflante Spiritu ${ }^{15}$, in which the Pope requires that the interpreter give the literal meaning of the Word of God, 
consulting history, philology, and the patristic interpretation under the guidance of the Church's magisterium. [...] there is always in our introductions a sketch of the historical background $[\ldots]$ there are many appendices $[\ldots]$ Nor have the great Fathers of the Church been neglected. [...] Besides the Fathers, we used the best modern commentaries, Catholic and non-Catholic, in order to understand the meaning of the sacred text and to propose it in clear, concise language.

The first complete version of the Catholic Chinese Bible received a warm welcome from many, including both biblical scholars and churchgoers. Allegra was satisfied with the translation as completed, but he felt that something more had to be done to make it more accessible for the people. For this reason, after 1961, he immediately started the revision work, together with his colleagues. They adopted a five-year plan to review the text and to prepare all the indices and appendices that would be published in the one-volume Bible. They succeeded in respecting the plan and on December 25, 1968, the single-volume Catholic Chinese Bible was published. This edition was distributed among the Chinese believers and was praised by many members of the church hierarchy. Some appendices included in it were particularly appreciated: chronological tables with Chinese and biblical history and dates, compared chronologies of Chinese emperors and Israeli kings, thematic and systematic indices, and maps of the biblical places.

All these features make the version of the Studium Biblicum a very precious one. In fact, it is still used today by the Chinese Catholics, even if other revisions and new translations have been made (Zetzsche 1999a, pp.418-422). As the linguistic excellence of this translation has been confirmed by American translator Eugene Nida, Sīgāo Shèngjīng is now worthy of a more detailed analysis, in order to better understand the above mentioned features.

\section{Translation analysis}

Before going through a detailed analysis, two features of the Studium Biblicum Version (SBV) ${ }^{16}$ must be underlined. They concern the translation of two words that in Protestant circles fueled many debates, while for the Catholics were soon well defined.

Firstly, to translate the term "God" (the Greek Theos or the Hebrew Elohim) the word chosen was Tiānzhŭ (天主), meaning “Lord of Heaven". For Allegra and his team it had not been difficult to fix this term because they, as all the Catholics, conformed to a papal decree that in 1742 ordered the use of the term Tiānzhŭ, dismissing the other several options used to refer to God. This issue concerned also the Protestant translators, who could not come to an agreement ${ }^{17}$ on the term to translate God, and decided to keep all of the alternatives, leaving the so-called "Term Question" 
unresolved (Eber 1999b). In particular, the most used term to translate “God" was Shàngdì (上帝), meaning "Highest Lord" or "Lord on High". This word, however, could confuse the Chinese, as it was the same name of a supreme being of the Shang and Zhou dynasties. Furthermore, the second character, dì (帝) was the same forming the disyllabic word huángdi (皇帝), meaning “emperor", thus creating the risk of misunderstandings and disorientation ${ }^{18}$.

Secondly, another term that created interesting debates was "baptism". Since their arrival in China, the Catholics had been using the Chinese term $x \check{l}$ (洗) meaning “to wash". It was accepted by many Protestant translators, but the missionaries of the Baptist Church did not accept this common Chinese word because they wanted to underline the most important moment of their rite of the Baptism, which was that of immersion. They proposed terms such as zhàn (蘸) and cuì (淬), meaning “to dip in”, or jin (浸) meaning "to soak". Nonetheless, the other Protestants preferred to use $x \grave{i}$ because it was "too late in the history of the Church in China to change the term $[x i]$ successfully. It is already imbedded in the language" (Zetzsche 1999a, p.55). To distinguish the verb from the noun indicating the rite of the baptism in Chinese, the latter is translated adding the character $l \check{l}$ (禮), meaning "ceremony".

It is now possible to examine some specific translation choices, narrowing the textual analysis to the New Testament for two reasons. One concerns the advantage of dealing with only one biblical language (New Testament Greek), and the other refers to the first stage of my research, underlining the need for further study.

As already mentioned above, a relevant aspect of the Betlem Bible is the great attention given to the transliteration. A clear example of this can be seen in the transliteration of the proper name "Peter". Respecting the Catholic tradition, the SBV transliterates Bóduōlù (伯多禄). The accuracy of this choice becomes evident if compared with the Protestant Bı̌dé (彼得). The first indeed resembles the original Greek name Petros, while the second clearly mirrors the English pronunciation of the name Peter. The same happens with the name "Mark", being Mǎerrgǔ (馬爾谷) the Catholic transliteration, and Măkě (馬可) the Protestant one; the first mirrors the Greek Marcos and the second mirrors the English Mark $^{19}$.

Good examples of the scientific translation of botanical names are those referring to "myrrh" and "nard". In Matt 2:11; Mark 15:23 and John 19:39, in which the term "myrrh" occurs, the Chinese word chosen is mòyà (沒 藥), which exactly means "myrrh". In Mark 14:3 and John 12:3, to translate “nard” the SBV uses a transliteration: nàěrduo (納爾多) or náérduō (拿爾多). It is always between quotation marks to indicate that is a transliteration of a proper name. Another case confirming careful attention to translation of the names of plants is that of the word "fig". In every occurrence, the translation 
is wúhuāguǒ (無花果), with the addition of shù (树) meaning “tree” when the plant and not the fruit is mentioned.

Some examples confirming the desire of the translators to respect the Semitisms are those of the words "Abba", "Pharisees" and "Sadducees". In the first case, the transliteration of the Aramaic word Abbà (Mark 14:36; Rom 8:15; Gal 4:6) meaning "Father", is given with the characters $\bar{A} b a ̀$ (阿 爸). For the "Pharisees" and the "Sadducees", two factions of Judaism, the Chinese words chosen to transliterate them are fălìsāi (法利塞) and sādùsāi (撒杜塞) - used as adjectives to which the noun rén (人), meaning “man”, is attached.

Another interesting case of translation is that of the units of measure - in particular the monetary ones. In Luke 15:8-9 there is the word "drachma" - an Israeli currency of the time. It is transliterated from the Greek also in English (and in Italian); in Chinese it becomes dámă (達瑪), with a footnote explaining its value. The case is similar with the word "denarius". In English it is transliterated from the Greek, and the sense of a foreign currency is kept also in the Chinese. The transliteration is dénà (德纳) in every occurrence referring to this monetary unit (i.e. Matt 18:28; 20:2.9.10.13; etc...).

In the SBV, one of the words maintaining the same translation of the traditional Christian terminology is “resurrection", fùhuó (復活), literally meaning, "live again". This term seems to transmit the meaning of the Christian resurrection better than the Protestant füsheng (復生), which could also mean, "born again," and could cause confusion with the Buddhist "reincarnation", zhuănshēng (轉生).

Another interesting translation choice of the SBV - and indeed a very frequent collocation in the Pauline epistles - is that of "word of God" or “word of the Lord". Allegra chose to use shèngdào (聖道) or dàoli (道理), which results in a very clear translation because the use of the word dào ( 道) indicates the concept of "the right way", and the presence of shèng (聖) or lǐ (理) prevents from creating confusion and misunderstandings with the Taoist meanings of Dào (道).

Up to this point of the analysis, the most remarkable translation choice of the SBV is that concerning the words chosen for "brothers". As in English, the Greek language does not have a linguistic distinction between elder and younger brothers, but this is a feature that the Chinese language does have. The word xiōng (兄) means “elder brother", and the word di (弟) means "younger brother"; matching the first and the second, we have the plural term "brothers", xiōngdi (兄弟), commonly used in Chinese. The interesting aspect of the translation by Allegra and his colleagues is that in every passage concerning the relationship among blood brothers, the term used is xiongdi, however in the passages concerning the brotherhood in God, we find the inverted term dixiōng (弟兄). This strategy seems to be very helpful in indicating the difference in relationship, especially in the Pauline epistles. 


\section{Conclusion}

This article has explored the features of the first Catholic Bible in Chinese. The importance of the version to be analyzed has been underlined through a brief exposition of the historical situation surrounding the translations of the Bible in Chinese before the activity of Allegra began. Furthermore, some relevant aspects of this historical background, such as diplomatic roles, oral preaching, the decrees of the Congregation for the Propagation of the Faith, and the main priorities of the Protestants, help to clarify how much the evolution of history and differing contexts influenced a similar activity.

The life and work of Gabriele Allegra, together with the founding of the Studium Biblicum Sinense and the activities of the scholars living there, are an invaluable way to learn about the meticulous work hidden behind every word of the translated Scripture. Allegra's autobiographical text, along with all his cited works, are sources of primary importance to better understand every phase of the translation process.

The concrete part of the study is found in the final textual analysis, in which the features previously exposed can be directly verified. Generally, the primary purpose of Gabriele Allegra and his co-workers can be confirmed; it was that of respecting the syntax and lexicon of the original texts - both Hebrew and Greek. In the analysis of selected passages and words of the New Testament presented it is evident that, though taking a risk in producing an unfamiliar text for Chinese readers, the principle of respecting the original was strictly observed. In particular, the occurrence of new Chinese terms (nàěrduō, fălìsāi dámă, dénà, etc.), even if creating a foreign effect in the text, can be appreciated for two reasons. First, it indicates to the readers that the events told in the Bible happened in a place different from China and in a time far from the $20^{\text {th }}$ century - a time and place in which the fălissāi lived, the nàěrduō was precious oil, and during which dámă, dénà, and other currencies were used to pay. Second, possible doubts about unknown or unclear meanings of words can be resolved by using the Chinese Biblical Dictionary - compiled just for this purpose. These conclusions show the strict adherence of Allegra's translation to the Greek text and his attention in avoiding confusion, confirming the appellation given to Allegra by some authors (Casini 1978; Gandolfi 1984; Oppes 2005), who referred to him as the "Saint Jerome of China"

Given the continuous evolution of every language, it is known that a $20^{\text {th }}$ century's translation needs to be reviewed for today. Many scholars are currently working in and outside China toward the modernization of the existing translations of the Chinese Bible and the preparation of new versions. Nevertheless, the fact that SBV is still used today by the Chines Catholics confirms the validity of this version and promotes further research on the topic. 


\section{References}

Abbiati, M., 1992. La lingua cinese. Venezia: Libreria Editrice Cafoscarina.

Aland, B., Aland, K., Karavidopoulos, J., Martini, C. M. and Metzger, B. M. (eds.), 1993. The Greek New Testament, Fourth Revised Edition. Stuttgart: Deutsche Bibelgesellschaft.

Allegra, G., 1953a. De Studio Biblico Franciscano Sinensi. In: Liber Annuus, III, pp.185-218.

Allegra, G. M., 1953b. Una pubblicazione della Bibbia in cinese. In: L'Osservatore Romano, 27 agosto, p.3.

Allegra, G. M., 1965a. The Chinese Version of the Holy Bible of Studium Biblicum O.F.M. Hong Kong. In: Teaching all Nations, July, pp.345-353.

Allegra, G. M., 1965b. Una esposizione biblica a Hong Kong. In: L'Osservatore Romano, 29 aprile, p. 6.

Allegra, G. M., 1966. Il primato di Cristo in S. Paolo e in Duns Scoto: dialogo col p. Teilhard de Chardin. Palermo: Crociata del Vangelo.

Allegra, G. M., 1969. Actuositas Studii Biblici Franciscani Sinensi: 1963-1969. In: Liber Annuus, XIX, pp.369-373.

Allegra, G. M., 1974. Quid circa cosmogoniam sinicam erui possit ex poemate "Quaestiones caelestes" a Ciu Yuan composito. In: Liber Annuus, XXIV, pp.70-93.

Allegra, G. M., 1975. De Lexico Biblico Sinico. In: Liber Annuus, XXV, pp. 269-277.

Allegra, G., 2008. Ormai il popolo cinese è al centro dei miei pensieri, trans. and ed. L. Goh. In: Quaderni Biblioteca Balestrieri, No. 9, III, pp.39-49.

Barriquand, F., 2011. Bible Translation in Chinese. In: Hong Kong Journal of Catholic Studies, No. 2.

Bays, D. H., 2011. A New History of Christianity in China. Chichester: WileyBlackwell.

Broomhall, M., 1934. The Bible in China. London: Religious Tract Society.

Buffon, G., 2008. La Bibbia in cinese di Gabriele Allegra: una traduzione lunga una vita. In: L'Osservatore Romano, 14 novembre, p.4.

Buzzetti, C., 1973. La Parola tradotta. Brescia: Morcelliana.

Buzzetti, C., 1984. La Bibbia e le sue trasformazioni. Brescia: Editrice Queriniana.

Cacciotti, A. and Melli, M. (eds.), 2013. I Francescani e la Cina. Un'opera di oltre sette secoli. Atti del X Convegno storico di Greccio. Greccio, 4-5 maggio 2012. Milano: Edizioni Biblioteca Francescana.

Camps, A., OFM, 1999. Father Gabriele M. Allegra, OFM (1907-1976) and the Studium Biblicum Franciscanum: The First Complete Chinese Catholic Translation of the Bible. In: Eber, I., Wan, S. and Walf, K. (eds.). Bible in Modern China: the Literary and Intellectual Impact. Sankt Agustin-Nettetal: Institut Monumenta Serica, pp.55-76.

Camps, A., OFM and McCloskey, P., OFM, 1995. The Friars Minor in China (1294-1955): especially the years 1925-55. New York: Franciscan Institute 
St. Bonaventure University and Rome: General Secretariate for Missionary Evangelization General Curia, Order of Friars Minor.

Carlino, M., 2008. La Parola di Dio si fa Libro in Cina. L'opera di P. Gabriele Allegra. In: Quaderni Biblioteca Balestrieri, No. 9, III, pp.127-144.

Casini, A., OFM (ed.), 1978. P. Gabriele M. Allegra O.F.M.: il s. Girolamo dell'Estremo Oriente. Repubblica di San Marino: Edizioni centro Frate Francesco.

Cingolani, S. 2008. Dizionario di critica testuale del Nuovo Testamento: storia, canone, apocrifi, paleografia. Cinisello Balsamo: San Paolo.

Congregatio De Causis Sanctorum, 1989. Positio Super Virtutibus Canonizationis Servi Dei Gabrielis M. Allegra, Sacerdotis professi O.F.M. (1907-1976), P.N. 1446. Roma: Tipografia Guerra.

Consoli, S. and Finocchiaro, C. (eds.), 2008. Frate Gabriele M. Allegra tra Cina e Sicilia, Bibbia e spiritualità. Atti del Convegno di Studi organizzato dall'Ordo Fratrum Minorum Provincia Siciliae "Sanctissimi nomini Jesu” e dello Studio teologico S. Paolo di Catania. Acireale, 29-30 novembre 2007. Catania: Studio teologico S. Paolo.

Eber, I., 1999a. Introduction. In: Eber, I., Wan, S. and Walf, K. (eds.). Bible in Modern China: the Literary and Intellectual Impact. Sankt Agustin-Nettetal: Institut Monumenta Serica, pp.13-30.

Eber, I., 1999b. The Interminable Term Question. In: Eber, I., Wan, S. and Walf, K. (eds.). Bible in Modern China: the Literary and Intellectual Impact. Sankt Agustin-Nettetal: Institut Monumenta Serica, pp.135-164.

Eber, I., Wan, S. and Walf, K. (eds.), 1999. Bible in Modern China: the Literary and Intellectual Impact. Sankt Agustin-Nettetal: Institut Monumenta Serica.

Foley, T. S., 2009. Biblical Translation in Chinese and Greek. Verbal Aspect in Theory and Practice. Leiden: Brill.

Gálik, M., 2004. Influence, Translation, and Parallels: Selected Studies on the Bible in China. Sankt Augustin-Nettetal: Monumenta Serica Institute.

Gandolfi, D., OFM, 1984. For China... Another Jerome: the Life and Work of Father Gabriele Allegra, trans. R. S. Almagno, O.F.M. and M. Mazuk. New York: Franciscan Province of the Immaculate Conception.

Gandolfi, D., OFM, 2003. Padre Allegra e la Bibbia in Cinese, le tappe di una traduzione. In: Antonianum, 78, pp.291-320.

Girardi, P. G.. PIME, 1969. La prima Bibbia Cinese tradotta dai testi originali. In: L'Osservatore Romano, 19 gennaio. pp.3, 8.

Gong Liang, 1999. Twenty Years of Studies of Biblical Literature in the People's Republic of China (1976-1996). In: Eber, I., Wan, S. and Walf, K. (eds.). Bible in Modern China: the Literary and Intellectual Impact. Sankt Agustin-Nettetal: Institut Monumenta Serica, pp.383-404.

Gozzo, S. M., OFM (ed.), 1986. "Memorie” autobiografiche del P. Gabriele M. Allegra O.F.M., missionario in Cina. Roma: Rotatori.

Grilli Caiola, M., Guarrera, P.M. and Travaglini A., 2013. Le piante nella Bibbia. Roma: Gangemi. 
I francescani e la Cina 800 anni di storia: atti della Giornata di studio in preparazione alla canonizzazione dei martiri cinesi. Santa Maria degli Angeli-Assisi, 9 settembre 2000, 2001. Santa Maria degli Angeli, Assisi: Porziuncola.

Nergaard, S. (ed.), 1995. Teorie contemporanee della traduzione. Milano: Bompiani. Nergaard, S. (ed.), 2002. La teoria della traduzione nella storia. Milano: Bompiani.

Nida, E. A., 1964. Toward a Science of Translating, with Special Reference to Principles and Procedures Involved in Bible Translating. Leiden: Brill.

Oliva, C., 1968. Un precursore della liturgia in lingua nazionale, P. Niccolò Longobardo S.I.. In: La Civiltà Cattolica, 2833 (3), pp.480-494.

Oppes, S., 2005. Le memorie di fra' Gabriele M. Allegra ofm, il "san Girolamo” della Cina. Città del Vaticano: Libreria Editrice Vaticana.

Qu Yuan, 1938. Li Sao. Incontro al dolore, trans. G. Allegra. Shanghai: no p..

Ren Xiaochuan, 2008. A Study of the Major English and Chinese Bible Versions throughout the History of Bible Translation. In: Asian Social Science, Vol. 4, No. 7, July, pp.51-53.

Ricci, M. and Trigault, N., 1983. Entrata nella China de' padri della Compagnia del Gesù (1582-1610). Roma: Edizioni Paoline.

Sabattini, M. and Santangelo, P., 2006. Storia della Cina. Bari: Gius. Laterza \& Figli.

Sella, P., 2008. Il Vangelo in Oriente. Giovanni da Montecorvino frate minore e primo vescovo in terra di Cina (1307-1328). S. Maria degli Angeli-Assisi: Edizioni Porziuncola.

Shèngjīng (聖經), 2009. Nanjing: Àidé yìnshuā yǒuxiàn gōngsī (愛德印刷有限公司). Smalley, W.A., 1991. Translation as Mission: Bible Translation in the Modern Missionary Movement. Macon: Mercer University Press.

Standaert, N., 1999. The Bible in Early Seventeenth-Century China. In: Eber, I., Wan, S. and Walf, K. (eds.). Bible in Modern China: the Literary and Intellectual Impact. Sankt Agustin-Nettetal: Institut Monumenta Serica, pp.31-54.

Standaert, N. (ed.), 2001. Handbook of Christianity in China, Vol. 1, 635-1800. Leiden: Brill.

Starr, C. (ed.), 2008. Reading Christian Scriptures in China. London-New York: T \& T Clark.

Tiedemann, R. G. (ed.), 2010. Handbook of Christianity in China, Vol. 2, 1800-Present. Leiden: Brill.

Vermander, B., 1996. Theologizing in the Chinese Context. In: Studia Missionalia, No. 45, pp.119-134.

Vermander, B., 2001. Jesus Christ and the Chinese Religious World. In: Studia Missionalia, No. 50, pp.391-405.

Wang Hui, 2008. Translating Chinese Classics in a Colonial Context: James Legge and His Two Versions of the Zhongyong. Bern: Peter Lang.

Wang Weifan, Rowold, S. and Rowold, H., 1993. The Bible in Chinese. In: Chinese Theological Review, No. 8, pp.100-123. 
Yariv-Lahor, L., 1999. Linguistic Aspects of Translating the Bible into Chinese. In: Eber, I., Wan, S. and Walf, K. (eds.). Bible in Modern China: the Literary and Intellectual Impact. Sankt Agustin-Nettetal: Institut Monumenta Serica, pp.101-122.

Zetzsche, J. O., 1999a. The Bible in China: the History of the Union Version or the Culmination of Protestant Missionary Bible Translation in China. Sankt Augustin-Nettetal: Monumenta Serica Institute.

Zetzsche, J. O., 1999b. The Work of Lifetimes: Why the Union Version Took Nearly Three Decades to Complete. In Eber, I., Wan, S. and Walf, K. (eds.). Bible in Modern China: the Literary and Intellectual Impact. Sankt Agustin-Nettetal: Institut Monumenta Serica, pp.77-100.

\section{Endnotes}

1 On the debate on the year of arrival of John of Montecorvino in China, see: Sella 2008, p. 66.

2 Regarding these letters see also: Willeke, B. W., 1966. Das Werden der chinesischen katolischen Bibel. In: Buhlmann, W., ofm Cap., and Specker, J., smb, (eds.). Die Heilige Schrift in den katholischen Missionen. Schoneck-Beckenried: Administration der Neuen Zeitschrift für Missionswissenschaft, p.285; and de Vincentiis, G., 1904. Documenti e titoli sul privato fondatore dell'attuale R. Istituto (antico "Collegio dei Cinesi" in Napoli) Matteo Ripa, sulle missioni in Cina nel secolo XVIII e sulla costituzione e consistenza patrimoniale della antica fondazione. Napoli: G. Salvati, p.126.

3 On the Jesuits in China see: Ryan, T. F., S.J., 1964. Jesuits in China. Hong Kong: Catholic Truth Society; Zürcher, E., Standaert, N. and Dudink, A. (eds.), 1991. Bibliography of the Jesuit Mission in China (ca. 1580 - ca. 1680). Leiden: Centre of Non-Western Studies, Leiden University; Brockey, L.M., 2008. Journey to the East: the Jesuit Mission to China, 1579-1724. Cambridge, Mass.: Belknap Press of Harvard University Press; Paternicò, L. M. (ed.), 2011. The Generation of Giants: Jesuit Missionaries and Scientists in China on the Footsteps of Matteo Ricci. Trento: Centro Studi Martino Martini.

4 He died in 1707, while translating the Epistle to the Hebrews, so only its end and the Book of Revelation were missing to the New Testament (Zetzsche 1999a, pp.28-32).

5 On the life and work of Robert Morrison see: Zetzsche 1999a, pp.31-57; Morrison, E., 1839. Memoirs of the Life and Labours of Robert Morrison, D.D., Compiled by his Wife. London: Longman; Townsend, W. J., 1890. Robert Morrison: the pioneer of Chinese missions. London: S.W. Partridge \& Co.; Daily, C., 2013. Robert Morrison and the Protestant Plan for China. Hong Kong: Hong Kong University Press.

6 Morrison had started learning Chinese in England. When he arrived in Canton he translated the New Testament alone. It was only in 1813 that another missionary arrived to help him. He was William Milne who collaborated on the translation of the Old Testament and on the revision of the whole Bible (Zetzsche 1999a, pp.41-43).

7 On the Catholic partial translations see: Camps 1999, pp.56-57.

8 On the activity of Allegra and his translation, also refer to the recent study by Choi and 
Mak: Choi, D. K. T. and Mak, G. K. W., 2014. Catholic Bible Translation in TwentiethCentury China: An Overview. In: Chu, C. Y., Catholicism in China, 1900-Present. The Development of the Chinese Church. New York: Palgrave Macmillan, pp.105-123. I was not able to refer to it since it only came out after the writing of the present article was already concluded.

9 The edition of the autobiographical memoirs consulted is: Oppes, 2005. Other editions of the memoirs are: Casini 1978 and Gozzo 1986. Many other personal diaries and letters of Allegra are preserved at the convent of San Biagio in Acireale, where he lived from 1918 to 1926, and where his tomb is currently located. Further research on them is needed.

10 As Camps (1999, p.66) recalls, "Allegra had studied the arrival and spread of Buddhism in China, and he was especially interested in the history of the translation of Buddhist Scriptures into the Chinese language. [...] Chinese Buddhist monks went to India for longer periods of time and studied the original languages of the Buddhist scriptures; on their return to China they began to collaborate with Indian monks on producing better and philologically more accurate translations".

11 On the Sociologial Studium see: Oppes 2005, pp.132-136.

12 Other Biblical Weeks and Biblical Expositions were held in Taiwan (January 3-10 1963) and Macau (March 16-22, 1969). See: Oppes 2005, pp.155-158.

13 The Chinese name of this version is Sìgāo Shèngjīng (思高聖經) - Sigao being the Chinese transliteration of the name of the Scottish Franciscan Duns Scotus (12661308).

14 On the projects of a biblical periodical and a biblical association and their achievement see: Oppes 2005, pp.173-175, 182-183.

15 For the complete English text of the encyclical see: Pius XII, 1943. Divino Afflante Spiritu. Available at $<$ http://www.vatican.va/holy_father/pius_xii/encyclicals/documents/hf_pxii_enc_30091943_divino-afflante-spiritu_en.html> [accessed 10 October 2014].

16 The version consulted is Shèngjing 2009.

17 This was additionally the result of the absence of a central authority among the Protestant missionary stations in China, which allowed every missionary to choose the option he preferred.

18 On the Term Question and the translation of "God" see also: A few Thoughts on the Question, What Term Can be Christianised for God in Chinese?, 1865. Shanghae: n.p.; Boone, W. J., 1848. An Essay on the Proper Rendering of the Words Elohim and Theos into the Chinese Language. Canton: n.p.; Burdon, J. S., 1877. The Chinese Term for God: a Letter to His Grace the Lord Archbishop of Canterbury. London: T. Williams; Burdon, J. S., 1877. The Chinese Term for God: a Letter to the Protestant Missionaries of China. Hong Kong: De Souza \& Co.; Chalmers, J., 1876. The Question of Terms Simplified: or, The Meanings of Shan, Ling, and Ti in Chinese, Made Plain by Induction. Canton: E-Shing; Eber 1999b; Inquirer, 1877. Part 1, Is the Shang-ti of the Chinese Classics the Same Being as Jehovah of the Sacred Scriptures?; Part 2, What Being is Designated Shang-ti in the Chinese Classics and in the Ritual of the State Religion of China?. Shanghai: Presbyterian Mission Press; Legge, J., 1852. The 
Notions of the Chinese Concerning God and Spirits: with an Examination of the Defense of an Essay, on the Proper Rendering of the Words Elohim and Theos, into the Chinese Language. Hong Kong: n.p.; Malan, S. C., Who is God in China, Shin or Shang-Te?: Remarks on the Etymology of Elōhim and of Theos and on the Rendering of those Terms into Chinese. London: Samuel Bagster \& Sons; Medhurst, W. H., 1847. A Dissertation on the Theology of the Chinese with a View to the Elucidation of the Most Appropriate Term for Expressing the Deity in the Chinese Language. Shanghae: n.p.; Medhurst, W. H., 1847. An Inquiry into the Proper Mode of Rendering the Word God in Translating the Sacred Scriptures into the Chinese Language. Shanghae: The Mission Press; Peet, L. B., 1852. Remarks on the Best Term for God in Chinese: Also on the Proper Basis of Compromise on This Subject: Addressed to the Friends of Protestant Missions to the Chinese. Canton: n.p.; Staunton, G. T., 1849. An Inquiry into the Proper Mode of Rendering the Word "God" in Translating the Sacred Scriptures into the Chinese Language: with an Examination of the Various Opinions Which Have Prevailed on this Important Subject, Especially in Reference to their Influence on the Diffusion of Christianity in China. London: Lionel Booth.

19 Other similar comparisons between Catholic and Protestant transliteration of biblical proper names can be made with examples from the Old Testament, as with the name of the prophet “Ezechiel”; the Catholic transliteration is Ėzékèerr (厄則克 耳) while the Protestant is Y̌xxījié (以西結).

20 Saint Jerome translated the Hebrew and the Greek texts of the Old and New Testament into Latin. His version goes under the name of Vulgate (Buzzetti 1984).

\section{About Author}

\section{Raissa DE GRUTTOLA}

She holds a Master's Degree in Foreign Languages (Chinese and English) from the Università degli Studi di Perugia. Since 2013 she is a $\mathrm{PhD}$ student at the Department of Asian and North African Studies of the Ca' Foscari University of Venice. Her research project is on Gabriele Allegra and the first translation of the Catholic Bible in Chinese. De Gruttola's field of research also includes the presence of Christians and Franciscan missionaries in China and the different versions of the Bible in Chinese. On these themes she has published "La Bibbia in Cina e la Bibbia in cinese. Storia delle traduzioni da Giovanni da Montecorvino a Gabriele Allegra" [The Bible in China and the Bible in Chinese. History of Translation from John of Montecorvino to Gabriele Allegra], in Antonianum, LXXXIX, 2-3, Apr-Sept 2014, pp. 247-276, and "Missionari in Cina: i primi francescani umbri" [Missionaries in China: the First Franciscans from Umbria]. In Bianchi E. and Parbuono D. (eds.), 2013. L'Umbria guarda la Cina. Perugia: Morlacchi Editore, pp. 59-68. raissa.degruttola@unive.it 